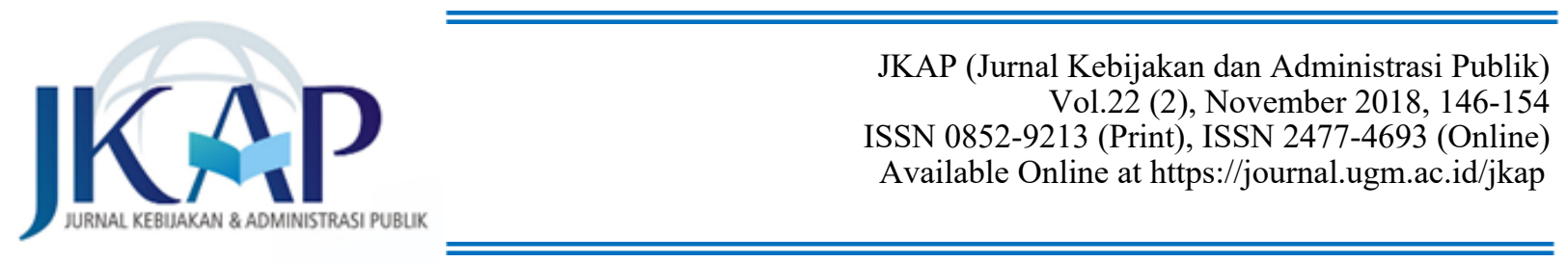

\title{
Bureaucratic Reform Barriers: A Case Study on the One Stop-Integrated Service Office in Bone Regency
}

\author{
Yusriadi Yusriadi \\ Sekolah Tinggi Ilmu Hukum Pengayoman \\ yusriadi.yusriadi@uqconnect.edu.au
}

\begin{abstract}
This research aimed at identifying the barriers to the implementation of bureaucratic reform, exploring the factors that cause these obstacles and offering some solutions to improve licensing administration services, this research applied the descriptive-qualitative approach using the case study design. Techniques of collecting data included interview, observation, and documentation. Instruments in this research, added the researcher himself (key device), an informant who was selected based on purposive sampling technique. Data analysis was based on "interactive models," including data collection, condensation, data presentation, and verification and concluding. The results showed that bureaucratic reform obstacles in licensing services, among others include, red tape and understaffing, while the internal environment in the bureaucracy and the various service user behavioral characteristics, were identified as critical barriers to bureaucratic reform. To that end, this research recommends conducting bureaucracy reform in all aspects, both internal to change bureaucracy itself) and external (induce changes in the characteristics of service user behavior).
\end{abstract}

Keywords: bureaucracy, bureaucracy reform, Indonesia, one-stop service, public service 


\section{INTRODUCTION}

The research on bureaucracy is complex; it deals with several aspects, such as human resources, government organizations, mechanisms, and procedures - government policy in the form of administration renewalbureaucratic reform. The overarching goal of bureaucracy reform is to improve the quality of public service delivery, through various policy measures. Besides the mindset of the bureaucracy, bureaucracy structure, availability of sufficient resources, communications, and disposition, have been identified as crucial for improving public service delivery.

One of the entry points that need intervention to improve public service delivery in Indonesia is changing the institutional framework. To that end, government intervention as manifested through the issuing of Permendagri Number 24 of 2006 on Guidelines of implementing One-Stop-Integrated Services, which compels the policy mandatory for local governments. One Stop Service (OSS) entails the management of the entire service provision process of both licensing and non-licensing activities right from the application phase to service delivery documentation in one place. OSS policy is underpinned by objectives that include the realization of fast, cheap, accessible, transparent, secure and affordable public services in line with people's rights to public services. Also, implementing OSS is aimed at attracting investment to local governments, as well as creating an enabling healthy and competitive business climate that is conducive to economic development. Some local governments that have implemented OSS show an upward trend over time. By the end of 2008, 329 local governments had established at least one-stop service unit (0SS).

Within the context of improving delivery of quality public services, by and large, depends on a well-functioning bureaucracy public service. Nonetheless, then a performance of bureaucracy faces many inherent obstacles that have associated with inefficiency, ineffectiveness, and low responsiveness. To improve public delivery one of the critical research areas in Public Administration Sciences is to identify factors that ham- per the performance of the bureaucracy, and by extension, provide solutions to various obstacles of bureaucracy (bureaucratic pathology). Consequently, the need to resolve bureaucracy pathologies is one of the key areas that has gained the attention and interest of public administration scientists, who are motivated by the desire to find solutions to barriers to bureaucratic reform (Caiden, 1991). Obstacles to bureaucracy performance include an absence of meritocracy (using the best talent); and appointments and promotion of that not based on competence, knowledge and skillset, fair competition and openness (Yusriadi, 2018a). Joint research by the World Bank and Gadjah Mada University (UGM), highlighted the rampant lousy image of the Indonesian bureaucracy in general and in the realm of public service delivery, this reflected in poor performance on of government bureaucracy on equity, responsiveness, service efficiency, bribery and rent-seeking (Dwiyanto, 2011)

In the context of public service delivery, government bureaucracy is a provider, while the community is the user. Understandably, the interests of providers and users differ. That said, bureaucracy as a service provider should attune its attention to serving service users, rather than, behaving as masters who receive services from servants (users). Such perception of the bureaucracy is evident in the attitude that government officials show in their interaction with users of public services. Based on grievances ventilated by many service users, government bureaucracy does not accord them the treatment they expect from them as civil servants who are there to serve their interests rather than those of the administration. Many public service users complain about rampant discrimination they face during public service delivery process.

To that end, interests of the government bureaucracy and service users (community members) tend to differ, concerning the process of public service delivery. It is a reality that runs counter to one of the critical goals and objectives of government bureaucracy, which is to ensure that service users receive the services they need with a high degree of certainty concerning timing, quality, fairness in access and cost, 
Yusri Adi - Bureaucratic Reform Barriers: A Case Study on the One Stop-Integrated Service Office...

and appropriateness to needs.

One of the problems that have identified as one of the sources of the problem is the mode of public service delivery that is by and large, highly decentralized. Nonetheless, the existence of OSS does not by itself resolve the issue entirely. This is due to a lot of ignorance that still abounds among public service users, about the licensing process itself, based on the testimony of one informant who is Rice Milling entrepreneur in Cumpiga Village, Awangpone Subdistrict, South Sulawesi; he expressed confusion and doubt about the process of processing the environmental impact analysis license for his firm. Indeed, the rice milling entrepreneur was not only surprised to learn that he was obligated to have such a license but also balked at the requirements he has to fulfill to obtain one (Turdi, 2014).

One type of public service delivered through OSS is the processing of Building Permits (Izin Mendirikan Bangunan [IMB]). The importance of the license is attributable to the fact that housing is one of the basic needs of the community, the fulfillment of which contributes to individual and community wellbeing. Nonetheless, many OSS service users, specifically those who have ever processed building permits, complain about the lack of clarity of the process, deviations in procedures, cost, and time between submission of applications and completion (Yunus, 2011).

In light of that, OSS performance while aimed at reducing obstacles that hamper the performance of government bureaucracy in the realm of public service delivery still faces problems that need resolving. The distribution of public services that relate to processing and issuing building permits is one such area that is bedeviled by poor performance. It is an obstacle that remains profound, despite reforms in the bureaucracy that aimed at improving performance, identifying the underlying factors that are attributable to the persistence of bureaucracy obstacles in delivering essential public services through OSS in the area of building permits processing, is thus, an exciting and relevant research topic to investigate.

\section{METHODS}

The case study used a qualitative research design. The focus of the research was on the implementation of OSS office in the processing of public services in Bone district, the choice of the research design based on its ability to explore experiences of informants about the delivery of public services through OSS. In-Depth interview technique was used to collect data from informants, who were selected based on purposive sampling technique, with additional criteria of being knowledgeable about delivery of services through OSS either as users or providers in Bone district. Meanwhile, data analysis based on Miles and Huberman interactive analysis model (Miles, Huberman, \& Saldana, 2014). Informants in this research comprised 3 (three) members of staffs in the administration of public services; head of the one-stop service (OSS); and 3 (three) individuals who have some experience in using public services delivered through OSS in Bone District. For robustness of the research results, validity was tested and verified through, ensuring, among other conditions a) persistence of observations, b) triangulation, and c) conducting crosschecks with peers of informants.

\section{FINDINGS AND DISCUSSION}

This section presents the analysis results of documents, observation, and outcome of interviews with informants.

\section{Form the obstacles of bureaucratic re- form in the licensing service}

Research results showed that the administration of OSS licensing services in Bone District faces several barriers that include:

\section{Red tape}

Red tape is interpreted as a convoluted and slow procedure in performing its duties as well as failure to and does not implement the existing various rules and procedures that exist (Bozeman \& Feeney, 2011). The existence of the red tape in licensing service can measure by the transparency indicator of the bureaucracy apparatus in delivering a specific service concerning cost, time, procedure and information. 
Concerning obstacles Bone district OSS licensing faces, an interview with VK, who is an OSS licensing officer, provided some insights into the scale of the problem. Interviews revealed that:

"...in delivering services, we do not discriminate between users. We as service officers are pleased to see people come directly to the office to apply for services because that equips them with knowledge about the requirements to obtain licensing permits. However, the reality is that not a few service users prefer to use the services of mediators instead of coming directly to our office to obtain public services. Our offices are always open to service users (Interview with VK in April 2016).

While from the perspective of service providers, there is no discrimination in the delivery of public services among applicants, the testimony obtained from RM, who has ever applied for licensing permits from OSS offices, revealed a starkly different story. The following excerpt of an interview underscored one of the severe problems that users of services delivered through OSS face.

\section{"While the terms of conditions in the processing of permits are clear as is the time required, based on my experience processing permits does not always follow the time set " (Interview with RM in May 2016)}

To that end, it is apparent that while there is a standard time set for the processing of permits, the reality is that the time required to do so is rarely commensurate with that standard. In other words, based on the testimony of one of the users of OSS licensing services in Bone district, there is an inconsistency between stipulated and actual time to complete the permit processing exercise. Consequently, users of services ventilate their disappointment with the time it takes officers to process permits by lodging complaints against the process. What is also important to note is the discrepancy between the time officials' state that is required to process permits and the actual time it takes to process the licenses (the latter is always longer than the former), underscores the persistence of low transparency in the delivery of licensing services.

Doubtless, the administration of licensing services is highly dependent on the organizational system, the behavior and the quality of the apparatus, and geographical conditions in the region. Areas that are expansive, remote and rugged suffer from relate underdevelopment, all of which factors undermine the pace of delivering public services, including operational permits. Nonetheless, an excerpt of an interview with $R G$, who has ever processed functions in the OSS, showed that not all users experience the same problems, an indication that indeed differential treatment occurs in the delivery of services (provided that both informants told the truth and nothing but the truth).

"The service in the office is pretty good as long as all the requirements met are submitted." (Interview with RG in May 2016)

There is thus, a difference in the perception of service providers on one hand who generally paint an optimistic note about the performance of OSS in delivering services on the one side and users of services who still complain about persisting obstacles in the delivery of services, especially the time it takes to obtain such services. It is also true, however, that even among service users, there is a difference in perception with some hailing the delivery of services as flawless, while others consider it still pledged with obstacles that need reforming. It must note that the informant who greeted OSS service delivery in Bone district used arguments normatively to substantiate the perception of good transportation, that is "as long as all the requirements fulfilled," which seems to put the blame on service users rather than providers. In general, thus, there is a dichotomy in the perception that informants have about the performance of service delivery using OSS in Bone district. While 
Yusri Adi-Bureaucratic Reform Barriers: A Case Study on the One Stop-Integrated Service Office...

service users perceive the service delivery process to riddle with obstacles that need improving, the bureaucracy considers the process flawless.

\section{Understaffing}

Therefore, public service organization must have in place intensive and systematic human resource recruitment and selection process in the process of selection and placement of human resources, namely, which must be underpinned by clear policies on job requirements that are commensurate with guidelines on job activities, duties, and responsibilities. In other words, human resource placement must be based on the principles of the right man in the right place. The importance of Human resource ineffective service delivery is attested by the impact that lack of adequate employees to serve in various roles in the delivery of OSS services in Bone district has undermined its performance - reflected in Table 1 that depicts Bone district OSS personnel by category and education attainment.

Based on the results of an interview with the MD (informant) who is a member of the OSS technical team, an absence of human resources with relevant competence and number was identified as one of the critical obstacles OSS service delivery faces in Bone district. Reflected in the content of the following interview:

\section{"... if you are referring to human} resources in this office, the number is far short of that required to execute various types of everyday work. For example, if in a day the office receives 20 applications on average, shortage of sufficient human resources with relevant skills leads to a backlog of applications that in the end slow down the process. Why is it slow? The answers are simply the absence of sufficient personnel "(interview with MD in March 2016)

Thus, based on the results of an interview with an OSS employee, OSS performance has been hampered by a lack of sufficient personnel with relevant qualifications.
The number of staff with adequate skills is far lower than that required to execute service delivery activities in such an urban area that serves many users.

Moreover, even among the existing employees, a good percentage of them serve on a temporary contract basis, not well skilled to do the activities they are involved in, leading to underperformance.

\section{Factors inhibiting bureaucratic reform in licensing services}

Public complaints about the performance of the bureaucracy are no longer new and are in part attributable to the among other factors, persistent corruption, slow service delivery, rigid service delivery procedures, red tape, and mindset that projects providers as wielders of authority instead of dedicated servers of public service users. In general, such conditions have undermined the concept of the Hegelian and Weberian bureaucracy that functions as a coordinator of various elements in the governance process. Consequently, multiple problems facing administration and conduct of the bureaucracy have created what many pundits have referred to as bureaucratic pathologies (Wahiyuddin, 2014). The bureaucracy wields enormous authority it dispenses in its capacity as the controller, disciplinary enforcer, and government organizer, but in no small extent neglects its role as the servant of the public (users). In summary, five factors have hampered bureaucratic reforms (Siagian, 1994) including 1) The perception and managerial style of officials in the bureaucracy whose behavior practices from principles of democracy. Consequently, various pathologies continue to bedevil the administration, including abuse of authority and position, accepting bribes, and nepotism. 2) Insufficient knowledge and skills of implementing officers in various units that charged with carrying of the delivery of public services, which has led to low productivity and service quality, and output that is fraught with mistakes. 3) Illicit conduct of officials including fraud and bribery. 4) Dysfunctional or harmful behavior of bureaucracy as manifested in arbitrariness of their work and procedures, shirking, and indulging in discriminatory activities while deliver- 
Table 1. Number of Licensing OSS apparatus

\begin{tabular}{lllll}
\hline No & School & $\begin{array}{l}\text { Government } \\
\text { employees }\end{array}$ & $\begin{array}{l}\text { Temporary } \\
\text { employees }\end{array}$ & Amount \\
\hline 1 & Master & 4 & 1 & 5 \\
2 & Bachelor & 9 & 14 & 23 \\
3 & Diploma & 1 & 1 & 2 \\
4 & Senior High & 2 & 13 & 15 \\
& School & & 29 & 45 \\
\hline Amount & 16 & 29 & \\
\hline
\end{tabular}

Source : OSS Licensing, 2016

ing duties; v) unconducive internal working environment that hampers effective delivery of responsibilities, including inadequate job and work conditions, lack of job descriptions and performance indicators, and absence of meritocracy in employee recruitment, selection, performance appraisal, and promotion.

The five barriers to bureaucratic reforms as proposed by Siagian (1994) reflected in the results the research finds on the OSS service delivery in Bone district. Public service delivery in Bone district continues to face a shortage of employee which had led to a situation whereby very few workers are working too much work, most of which goes unrewarded and also important, is the behavior of service users, which sometimes hampers the effectiveness of public service officials in delivering their duties. Nonetheless, while problems that inhabit the effectiveness of bureaucratic reform may vary by institution, based on the research by Siagian (1994) and results of this study, can be broadly categorized into two dimensions, namely, culture and behavior, the following section elucidates on the two aspects:

\section{The internal working conditions in OSS of-} fice

The internal working conditions in the bureaucracy who is reflected in the availability of adequate quality human resources apparatus to implement the necessary tasks and functions of the organization, human resource management, leadership management style, and state of facilities influence productivity. Bone OSS faces a shortage of skilled personnel to undertake critical activities which is why the office hired semipermanent workers who are employed on contract basis hence not as motivated to do their work as permanent civil servants, the problem that can link to the quality of leadership management style, competence, and initiative. Whatever the cause, lack of adequate human resources to serve in various capacities in OSS office is a key obstacle, irrespective of whether it is the responsibility of the leadership or bureaucratic red tape that obstructs employment of a sufficient number of right employees in right positions, has harmed performance.

An effective organization must have advanced planning for human resource demand in the future and how to fulfill that demand through various supply scenarios barring the existence of advanced human resource development planning. The organization faces difficulties to ensure that they have the necessary. Thus, the reality of semipermanent employees in OSS personnel is indicative of a lack of proper workforce planning that is necessary for successful public service delivery now and in the future. Results from interviews with OSS officials highlighted the problem as well.

Based on the excerpt of an interview with OSS licensing technical team lack of proper planning human resource planning, by constraining the availability of sufficient number of qualified personnel to carry on various vital activities in the organization was responsible for some of the obstacles such as delay in the delivery of services, underperformance as reflected in poor quality of products issued to users, discrimination 
Yusri Adi - Bureaucratic Reform Barriers: A Case Study on the One Stop-Integrated Service Office...

that some users experienced during the service delivery process, and uncertainty of procedures. The MD technical team put succinctly in the following words:

"Here we still face a shortage of human resources, which is why the number of temporary employees surpasses that of permanent employees. The only way to overcome a problem is to recruit new employees as well as strengthen the technical team. Achieving that will enable the organization to serve members of the public by the recommended public service delivery standards and procedures" (Interview with MD in March 2016).

The outcome of the above interview, thus, underscores the importance of human resource planning for effective and efficient public service delivery. The lack of the same in OSS Bone service delivery has resulted into significant obstacles that have continued to affect the delivery of quality services to users, undermining the critical objective of integrating public service delivery of various functions in a single location.

The external environment public service users face

Obtain a comprehensive view of the public service delivery process; this research assessed both sides of the civil service delivery process: providers (bureaucracy) and users (the general public). Based on primary data and empirical findings, the research has established that bureaucratic reform in general and those implemented in the public service delivery, face both internal and external factors, with the former attributable to elements within the public service delivery process, while the latter is associated with characteristics and behavior of users. Specifically, both internal and external environment is in part to blame for some of the pathologies that plague public service delivery among others, including, unhealthy competition among users which leads to corruption, exclusivity, and discrimination among service users perpetrated by the bureaucracy. Such condition was evident in an outcome of an interview the research team had with the MS, who is an informant that has had ample experience in processing licensing permits in OSS offices in Bone district:

"I processed an operational license a few weeks ago, on my own, though I requested for help from one of the employees who happens to be an acquaintance of mine. I do not think there is need to mention his name, to avoid any unwarranted eventualities. I gave him some small money, understandably to supplement the income he needs for his upkeep, which I deem OK" (Interview with MS in May 2016)

As if to underscore the reality on the ground that bribery in the delivery of licenses has become common practice, another informant who has processed licenses in OSS offices on several occasions in the past acknowledged that he prefers processing permits through intermediaries which are quicker albeit at the expense of paying higher charges.

"I prefer handling permits processing through brokers due to quicker results. It is fine with me if I spend extra money which compensates for the faster pace that employees at OSS offices handle my applications. The advantage of using brokers is both quicker and cost-effective in terms of time and money spent compared with handling the applications on my own" (Interview with $A D$ in May 2016)

The results of the interviews with the two informants who have had some experienced in processing license permits with Bone district OSS offices in the past revealed that bribery is still rife and benefits both users who prefer paying additional charges that serve as other income for public service providers. It was also evident in one of the interviews friendship and having fam- 
ily relations with providers of enables users to enjoy more comfortable and quicker access to licensing services in Bone district. Bribery remains rife primarily due to the acceptance of extra fees by both users and providers as part and parcel of the public service delivery process. To that end, one of the ways to mitigate the chances of bribery in the delivery of public services, providers should convey all the necessary information that users need to obtain services at OSS offices. Through socialization campaigns, carried through direct and indirect means that way, all prospective users of public services will have equal opportunity to have access to services they need, reducing possibilities of nepotism, bribery, and discrimination.

\section{CONCLUSION}

The objective of the study to identify obstacles facing bureaucratic reforms in Bone district, specifically in the delivery of public services through OSS office, obstacles facing bureaucratic changes can be broad categories into internal and external factors. Results of interviews with public service providers and users revealed a stark dichotomy between providers and users in the perception about the existence of lingering problem affecting the processing of operational permits. While the former underscored the persistence of various obstacles, the latter on the contrary, considers absence of the same in most cases except for incidents where the blame was put squarely on the behavior of users. That said, in general, key obstacles identified included red tape, which is strongly linked to rigid procedures that underpin public service delivery, insufficient human resources, mindset of civil servants that fails to appreciate the importance of users as the main reason for the work they do, leadership, behavior of users , discrimination among users, and corruption.

To that end, the research findings are very much in line with results of the Governance and Decentralization Survey (GDS) 2002 (Dwiyanto, 2011) that showed that the majority of service users tend to prefer to pay additional charges to quicken the pace at which they receive services. In light of that, both users and providers of public services are to blame to lingering pathologies that continue to plague the bureaucracy, including corruption.

Persistence of discrimination in public service is a bureaucratic disease despite being at odds with the principle of impersonality in public service delivery (Weber, 2009), is another problem that continues to bedevil public service. The principal promotes the conduct of public services in a fair and nonpartisan manner.

\section{ACKNOWLEDGEMENTS}

This research received the support of the Ministry of Research, Technology, and Higher Education. Indebtedness also goes to the One-Stop Integrated Service and Investment Office for the opportunity to conduct this research from start to end.

\section{REFERENCES}

Bozeman, B., \& Feeney, J. (2011). Rules and Red Tape: A Prism for Public Administration Theory and Research. New York: M.E. Sharpe Inc.

Caiden, G. E. (1991). Administrative Reform Comes of Age. New York: W. de Gruyter.

Denhardt, R. B., \& Denhardt, J. V. (2003). The New Public Service Serving Rather Than Steering. New York: M.E. Sharpe

Dwiyanto, A. (2011). Mengembalikan Kepercayaan Publik Melalui Reformasi Birokrasi. Jakarta: Gramedia Pustaka Utama.

Miles, M. ., Huberman, A. ., \& Saldana, J. (2014). Qualitative Data Analysis, A Methods Sourcebook (3rd Ed.). USA: Sage Publications.

Robbins, P. S. (1994). Teori Organisasi: Struktur, Desain dan Aplikasi. Jakarta: Arcan.

Setyati, R. and Utomo, W. (2015). Implementasi Kebijakan Penataan Ruang Terbuka Hijau Kawasan Perumahan Kota Banjarbaru. Jurnal Kebijakan Dan Administrasi Publik, 19(1), 59-70.

Siagian. (2000). Administrasi Pembangunan. 
Yusri Adi - Bureaucratic Reform Barriers: A Case Study on the One Stop-Integrated Service Office...

Jakarta: Bumi Aksara.

Siagian, S. P. (1994). Patologi Birokrasi: Analisis, Identifikasi dan Terapinya. Jakarta: Ghalia Indonesia.

Turdi. (2014). Pengusaha PB Bone Belum Paham Izin Lingkungan. Retrieved from http:// www.bonesatu.com/2014/06/pengusaha -pb-bone-belum-paham-izin.html

Wahiyuddin, L. O. (2014). Politisasi Pejabat Struktural Eselon II di Lingkungan Sekretariat Daerah Kabupaten Muna Sulawesi Tenggara. Jurnal Kebijakan Dan Administrasi Publik, 18 (1), 53-65.

Weber, M. (2009). The Protestant Ethic and the Spirit of Capitalism (Terjemah). Yogyakarta: Pustaka Pelajar.

Yunus, R. (2011). Kualitas Pelayanan Publik Pemerintah Daerah (Kasus Pelayanan IMB pada KPTSA Kabupaten Bone). Otoritas Jurnal Ilmu Pemerintahan, 1 (2), 137-145. Retrieved from http:// journal.unismuh.ac.id/index.php/

Otoritas/article/view/28
Yusriadi. (2018). Manajemen Perubahan dalam Reformasi Birokrasi menuju Information Technology (IT). Jurnal Mitra Manajemen, 2 (2), 61-70. Retrieved from http://www.ejurnalmitramanajemen.com/index.php/ $\mathrm{jmm} /$ article/view/39

Yusriadi, Akib, H., \& Ihsan, A. (2017). Bureaucratic Reform in Public Service: A Case Study on the One StopIntegrated Service. Mediterranean Journal of Social Sciences, 8 (2), 253 -258. https://doi.org/10.5901/ mjss.2017.v8n2p253 